\title{
HEAT FLOW MEASUREMENTS ON A HYDROTHERMALLY-ACTIVE, SLOW-SPREADING RIDGE: THE ESCANABA TROUGH
}

\author{
Dallas H. Abbott
}

\author{
College of Oceanography, Oregon State University
}

Janet L. Morton and Mark L. Holmes

U.S. Geological Survey, Menlo Park, CA

\begin{abstract}
Maximum heat flow measurements at three locations in the sediment-filled Escanaba Trough of the Gorda ridge exceed $1200 \mathrm{~mW} / \mathrm{m}^{2}$. At other ridge crests with thick sediment cover, heat flow values of this magnitude are accompanied by high temperature hydrothermal vent activity and massive sulfide deposition. A dredge haul from the southernmost high heat flow location recovered pyrrhotite, thereby confirming the presence of recent high temperature venting.
\end{abstract}

\section{Introduction}

The Escanaba Trough is a slow spreading ridge with a total opening rate of $3.0 \mathrm{~cm} / \mathrm{yr}$ [Riddihough, 1980]. At the time that this study was proposed, no active high temperature $\left(>100^{\circ} \mathrm{C}\right.$ ) hydrothermal vents had ever been found on a slow spreading ridge. Since that time, high temperature 'black smokers' have been found at two locations on the slow-spreading mid-Atlantic ridge [P. Rona, 1985; Weisburd, 1986]. These discoveries have destroyed the myth that massive-sulfide deposition at the sediment-water interface requires a rapid spreading rate [Skinner, 1983].

The Escanaba Trough differs in one fundamental respect from the areas of high temperature activity on the mid-Atlantic ridge. Unlike most ridge crest areas, most of the axis of the southern Gorda ridge is covered with over 100 meters of sediment. Consequently, sedimentary heat flow measurements could be used to determine the level of hydrothermal activity in the Escanaba Trough.

\section{Tectonic Setting}

Sedimentation on the Gorda ridge is dominated by turbidites originating on the North American continental margin and entering the rift valley at its southern end [Moore, 1970]. The thick sediment cover allowed us to perform detailed measurements of the heat flow along the axis, the first such study of a sediment-covered, slow spreading ridge. Prior to our study, fewer than 5 heat flow measurements had been made within 20 kilometers of the axial valley [Wilde et al., 1.979].

The sediment-filled Escanaba Trough is punctuated by 6 major volcanic edifices, labelled $A$ through $F$ from north to south (Figure 1). According to one theory [Francheteau and Ballard, 1983], local topographic highs on the ridge crest are the locations of the most recent and most intense hydrothermal activity. Because the most recent areas of voluminous volcanic extrusion are the least likely to be buried by sediment, local highs are usually the youngest portions of a sediment-covered ridge crest. Consequently, we concentrated our heat flow studies on the two highest volcanic edifices with sufficient sediment cover, $B$ and $D$.

Copyright 1986 by the American Geophysical Union.

Paper number 6L6984.

0094-8276/86/006L-6984\$03.00

\section{Measurement Technique}

Total heat flow is the thermal gradient multiplied by the sedimentary thermal conductivity. Temperatures were determined by standard techniques [Anderson et al., 1979], with the exception of a correction for frictional heating of the thermistors by penetration into the sediment. We were unable to perform precise corrections for frictional heating because our unusually heavy corehead sank slowly into the bottom sediments for the duration of most stations. Fortunately, we could use previous heat flow results from 'normal' heat flow stations in terrigenous sediments to estimate the maximum errors which could result from ignoring frictional heating. At all of the Escanaba stations, we measured the thermal gradient 6 minutes or more after the initial penetration. Once past the first 2 minutes at a 'normal' heat flow station, the maximum amplitude of the temperature change caused by frictional heating is at most $0.05^{\circ} \mathrm{C}$. The average amplitude is $0.01^{\circ} \mathrm{C}$. At the sites with the lowest thermal gradients, this could produce a maximum error of $20 \%$ and an average error of $4 \%$. This error is quite small, and its major effect is that we cannot determine if any non-linearities in the thermal profile are caused by water advection through the sediment. This error would not obscure the regional variability in heat flow, given by the ratio of the minimum to the maximum heat flow, equal to 1: 10.3 (Table 1).

Other potential sources of error in the thermal gradient measurements include bottom water temperature changes, lance bending, non-vertical penetration, and high sedimentation rates. Because the average errors in the linear regressions of the thermal gradients are $3.7 \%$ (Table 1), the first two can be eliminated as major causes of error. The minimum sedimentation rate in the southernmost Escanaba

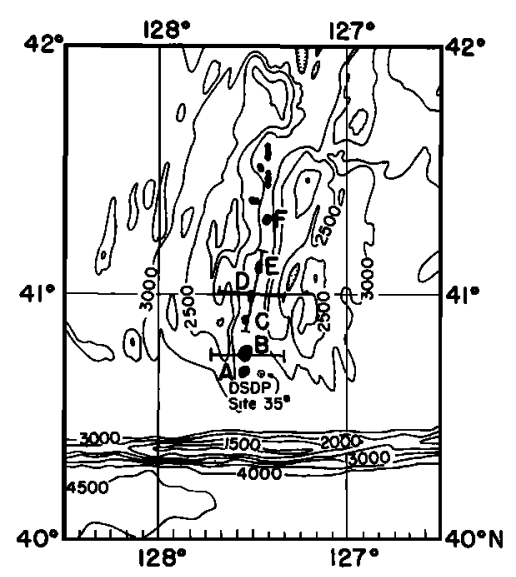

Fig. 1. Map of the survey area. Volcanic edifices $A$ through $F$ are along the axis of the Escanaba Trough north of the Mendocino Fracture Zone. Dotted circle: DSDP site 35 Lines: cross sections in Figures 2 through 4 . Bathymetry after Wilde et al. [1979]. Contour interval 500 meters. 
TABLE 1. Heat flow measurements from the Escanaba Trough. Column headings are from left to right: station number, heat flow, error in linear regression line fit of temperature versus depth, total error in heat flow, latitude of station, longitude of station, and number of thermistors in the bottom (number of thermistors on scale if different). Individual temperatures are accurate to $\pm 0.005^{\circ} \mathrm{C}$ [Anderson et al., 1979]. Starred linear regression errors were not included in the calculations of the average error. Starred errors are derived from the known variations in the penetration depth of the heat flow lance or the average linear regression error itself. Heat flow values are starred to designate the instrument tilt during the station: $0-10^{\circ}=$ no stars (tilt error $\pm 0.5 \%$ ); $10-40^{\circ}=$ one star (tilt error \pm $15 \%$ ) $; 40-60^{\circ}=$ two stars (tilt error $\pm 35 \%$ ). Because of our heavy corehead, tilts in excess of $60^{\circ}$ would cause the instrument to fall over. Stations 22-28 are transponder navigated. The remainder are Loran $C$ navigated.

Sta. Heat Lin Total Latitude Long Therm. \# Flow, Regr. Error, $\mathrm{mW} / \mathrm{m}^{2}$ Err., \% \% Deg N Deg W (on Sc.)

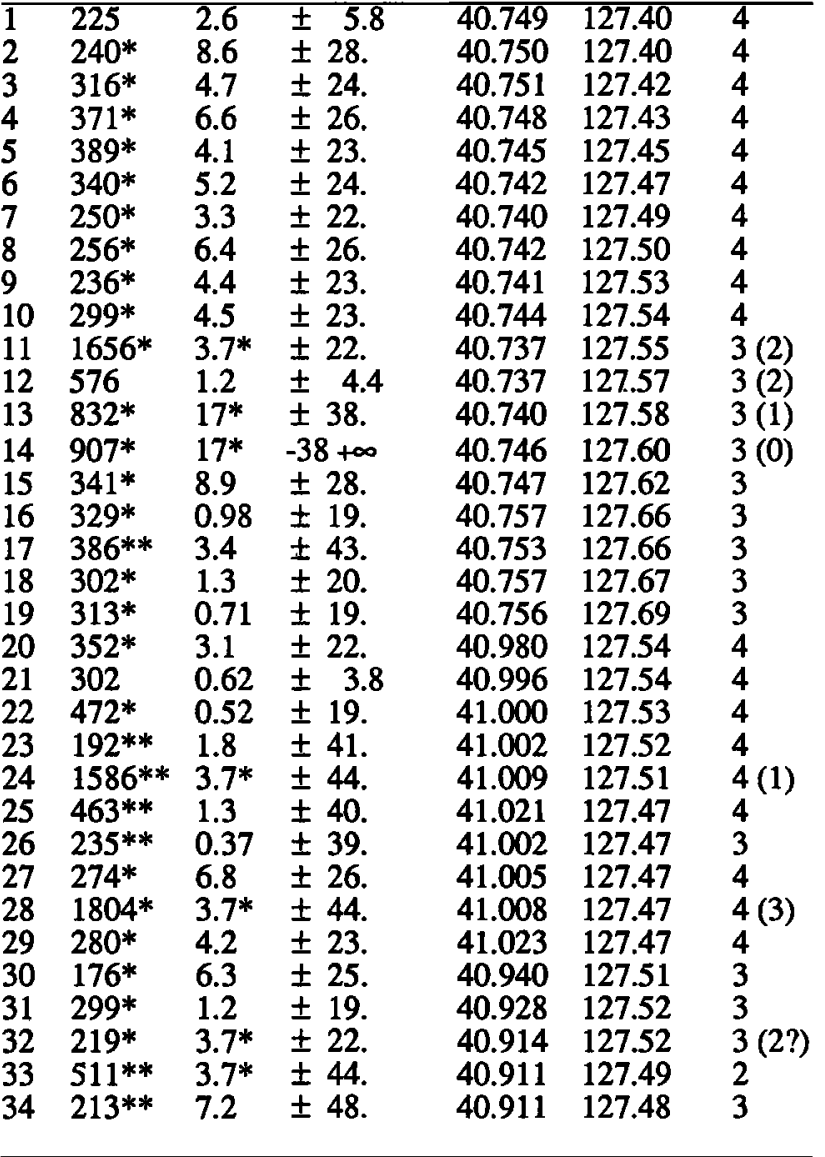

Trough is $560 \mathrm{~m} / \mathrm{my}$ [McManus et al., 1970], enough to cause an $8 \%$ lowering of the thermal gradients in the sediment column [Langseth et al., 1981]. Sedimentation rates are somewhat lower at edifices $B$ and $D$.

Thermal conductivity was determined using the methods of Lachenbruch and Marshall [1966]. The average thermal conductivity at $230 \mathrm{~cm}$ depth is $0.803 \pm 0.021 \mathrm{~mW} / \mathrm{mK}-\mathrm{m}$ in rift valley wall sediments (stations 16-19) and $0.882 \pm 0.021$ $\mathrm{mW} / \mathrm{mK}-\mathrm{m}$ in rift valley sediments (all other stations).
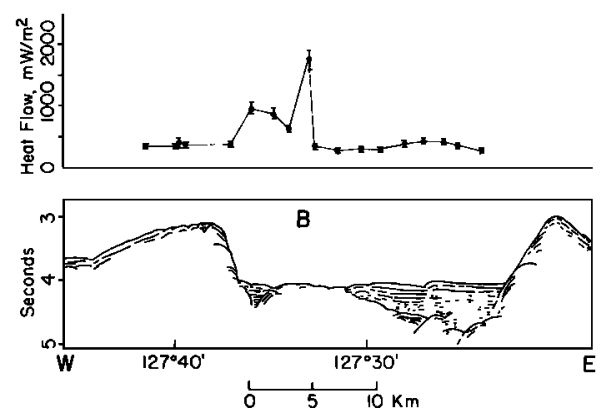

Fig. 2. Top, heat flow from west to east at $40.75^{\circ} \mathrm{N}$ (edifice $B$ ) in the Escanaba Trough. Heat flow stations 1-19 (Table 1). Bottom, Seismic reflection profile in seconds of two-way travel time along the same west-east line as the heat flow profile.

Total error in the heat flow, $\mathrm{Th}$, is: $\mathrm{Th}=(\mathrm{El})(\mathrm{Ec})(\mathrm{Et})$, where $\mathrm{El}$ is the error in the linear regression of temperature change versus subbottom depth, $\mathrm{Ec}$ is the error in the thermal conductivity $( \pm 2.6 \%)$, and $\mathrm{Et}$ is the error due to instrument tilt $(0.5$ to $35 \%)$. The maximum error at any one station is \pm $48 \%$ (Table 1). If the true heat flow did not vary among different stations, this error could produce a spurious ratio of minimum to maximum heat flow of $1: 2.85$. This spurious ratio would not obscure regional heat flow trends.

\section{Results}

The heat flow values obtained near edifices $B$ and $D$ have been plotted on two east-west cross sections (Figures 2, 3). At edifice B (Figure 2), the high heat flow zone is displaced somewhat to the west of the center of the rift valley. At edifice D (Figure 3), the high heat flow zones are near the edge of the volcanic edifice. On both of these profiles, the highest heat flow values $\left(>550 \mathrm{~mW} / \mathrm{m}^{2}\right)$ are within $4 \mathrm{~km}$ of the volcanic edifices.

The maximum heat flow values at both edifices are in excess of $1200 \mathrm{~mW} / \mathrm{m}^{2}$. At all other well-studied, sediment-covered ridge crests, the Guymas basin [Williams et al., 1979] and Middle Valley [E. Davis, personal communication], preliminary surveys measured a maximum heat flow in excess of $1200 \mathrm{~mW} / \mathrm{m}^{2}$. Later surveys in both

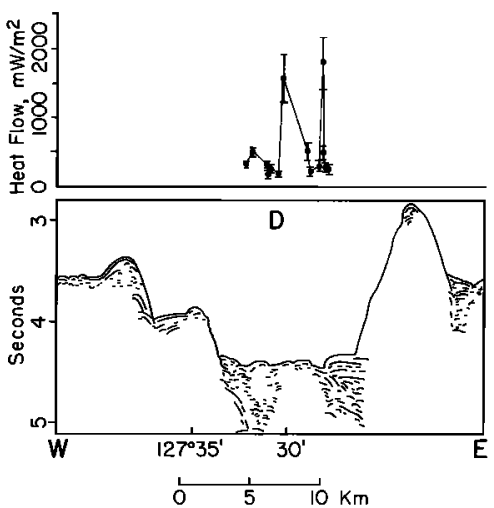

Fig. 3. Top, heat flow from west to east at $41^{\circ} \mathrm{N}$ (edifice D) in the Escanaba Trough. Heat flow stations 20-34 (Table 1). Bottom, seismic-reflection profile in seconds of two-way travel time along the same east-west line as the heat flow profile. 

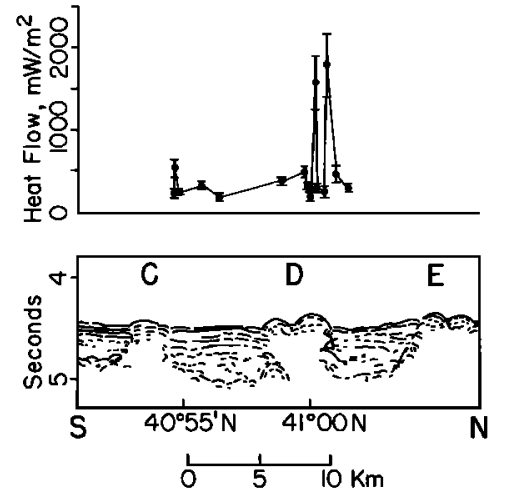

Fig. 4. Top, heat flow in $\mathrm{mW} / \mathrm{m}^{2}$ from south to north along the axis of the Escanaba Trough. Heat flow stations 1-15, 20-34 (Table 1). Bottom, Seismic reflection profile in seconds of two-way travel time along the same north-south line as the heat flow profile. Volcanic edifices $\mathbf{C}$ through $\mathrm{E}$ are labeled above the line.

areas found 'black smokers', active high-temperature, hydrothermal vents which discharge sulfide minerals. This implies that the Escanaba Trough also has 'black smoker' vents. Samples from dredge hauls provide supporting evidence for ongoing high temperature activity in the Escanaba Trough. Dredges at both edifice $B$ and $D$ recovered fresh basaltic glass. One dredge at edifice $B$ recovered samples of pyrrhotite [Holmes and Morton, 1986], a sulfide mineral formed during diagenesis at temperatures $\geq 300^{\circ} \mathrm{C}$ [Gieskes et al., 1982].

Unfortunately, our heat flow measurements from the area between edifices $B$ and $D$ are inconclusive with respect to high temperature hydrothermal activity. All of these measurements between edifices are from the center of the axial valley (Figures 1,4). If we had confined our efforts at edifice B to the center of the valley, we would not have measured any heat flow values in excess of $1200 \mathrm{~mW} / \mathrm{m}^{2}$. Consequently, further measurements are necessary before we can gage the amount of geothermal activity in the remainder of the Escanaba Trough.

\section{Conclusions}

The maximum heat flow measurements at volcanic edifices $B$ and D in the Escanaba Trough exceed $1200 \mathrm{~mW} / \mathrm{m}^{2}$. These high values, coupled with dredged pyrrhotite and fresh basaltic glass, indicate that high-temperature $\left(>100^{\circ} \mathrm{C}\right)$ hydrothermal venting is very likely to be occurring in this area. We cannot evaluate the geothermal potential of the rest of the Escanaba Trough on the basis of our present data. However, these results confirm that slow spreading ridges can produce intense hydrothermal activity at the sediment-water interface.

Acknowledgements, We thank G. Moore, D. Wilson, M. Lyle, V. Kulm, C. Stein, and W. Menke for critical comments and Captain A. McClenaghan and the crew of the S.P. Lee for help during the cruise. This research was supported by the
Department of Geology and Mineral Industries of the State of Oregon and by the U.S. Geological Survey.

\section{References}

Anderson, R.N., M.A. Hobart, and M.G. Langseth, Convective heat transfer in oceanic crust and sediment in the Indian Ocean, Science, 204, 828-832, 1979.

Francheteau, J., and R.D. Ballard, The East Pacific Rise near $21^{\circ} \mathrm{N}, 13^{\circ} \mathrm{N}$, and $20^{\circ} \mathrm{S}$ : Inferences for along-strike variability of axial processes of the mid-ocean ridges, Earth Planet. Sci. Lett. 64, 93-116, 1983.

Gieskes, J.M., M. Kastner, G. Einsele, K. Kelts, and J. Niemitz, Hydrothermal activity in the Guaymas basin, Gulf of California: A synthesis, in Curray, J. R., Moore, D.G., et al., Init. Repts. DSDP, 64: Washington, U.S. Govt. Printing Office, pp. 1159-1167, 1982.

Holmes, M.L., and J.L. Morton, Massive sulfide deposits from Escanaba Trough, Gorda Ridge (abs.), Geol. Soc. Am. Abstracts with Prog, 18. 118, 1986.

Lachenbruch, A.H., and B.V. Marshall, Heat flow through the Arctic Ocean floor: The Canada Basin-Alpha Rise boundary, J. Geophys. Res, 71, 1223-1248, 1966.

Langseth, M.G., M. A. Hobart, and K. Horai, Correction to 'Heat Flow in the Bering Sea,' J. Geophys. Res. 86, 1104, 1981.

McManus, D.A., et al., Init. Repts. DSDP, 5, Washington, U.S. Govt. Printing Office, pp. 761-773, 1970.

Moore, G.W., Sea-floor spreading at the junction between Gorda Rise and Mendocino Ridge, Geol. Soc. Am. Bull. 81, 2817-2824, 1970.

Riddihough, R.P., Gorda plate motions from magnetic anomaly analysis, Earth Planet.Sci.Lett., 51, 163-170, 1980.

Rona, P., Black smokers and massive sulfides at the TAG hydrothermal field, Mid-Atlantic Ridge $26^{\circ} \mathrm{N}$ (abstract), EOS Trans. AGU, 66, 936, 1985.

Skinner, B.J., Submarine volcanic exhalations that form mineral deposits: An old idea now proven correct, in Hydrothermal Processes at Seafloor Spreading Centers, edited by P. Rona et al., pp. 557-570, Plenum Press, New York, 1983.

Weisburd, S., Leg 106 treats: Hot vents, sea creatures, engineering feats, Science News, 129, 54, 1986.

Wilde, P., T. Chase, M. Holmes, W. Normark, J. Thomas, D. McCulloch, and L. Kulm, Oceanographic data off northern California-southern Oregon $40-43^{\circ} \mathrm{N}$ including the Gorda deep-sea fan, Lawrence Berkeley Laboratories, Publication 251, University of California, Berkeley, 1979.

Williams, D.L., K. Becker, L.A. Lawver, and R.P. Von Herzen, Heat flow at the spreading centers of the Guymas Basin, Gulf of California, L. Geophys. Res. 84, 6757-6769, 1979.

Dallas Abbott, College of Oceanography, Oregon State University, Corvallis, OR 97331. Janet Morton and Mark Holmes, U.S. Geological Survey, Menlo Park, CA 94025.

(Received: May 13, 1986;

accepted: June 4, 1986) 